DOI: $10.1177 / 0305829817714064$

Millennium: Journal of International Studies

\title{
The Erasure of Race: Cosmopolitanism and the Illusion of Kantian Hospitality ${ }^{1}$
}

\author{
J. K. Gani \\ University of St Andrews, UK
}

\begin{abstract}
This article explores three key arguments: Firstly, it seeks to demonstrate the contradictions and limits within Kantian hospitality, and its links to colonialism and practices of racialisation. The acclaimed universalism of Kant's law of hospitality forecloses a discussion of its dualism, and erases the historical, racist context in which it was conceived. The prioritisation of concept over conception allows Kant's theory on race to be obscured from official discourse and framing of policies while it still courses through inherited perceptions and theories. Secondly, in making my case, I will be applying the notion of coloniality, coined by Aníbal Quijano and later developed by Walter Mignolo, to the existing but small body of critical discourse on Kant and race. Debates initiated on the peripheries of philosophy, law and anthropology in the 1990s have led the way in this regard. However, given the time that has elapsed, it is notable that their work has received little scrutiny in political theory and International Relations theory, and thus warrants renewed attention - I argue that the notion of coloniality provides a useful lens through which to do so, and a vehicle through which to apply those excavations to a contemporary context. Finally, the article explores the extent to which Kantian thought constitutes 'modern' cosmopolitanism, and draws attention to the inadvertently complicit role of second-generation cosmopolitans in the erasure of race from the study of Kant. The relationship between the collective erasure of race and racism in academia and European practice towards refugees and immigrants is briefly considered.
\end{abstract}

\footnotetext{
${ }^{1}$ Accepted version. See DOI for final published version.
} 


\section{Keywords: Kant, race, hospitality Introduction}

The European Union's response to the refugee crisis and the current political malaise of the so-called 'West' makes it imperative to (re)assess theories of hospitality and the complacency of cosmopolitanism. The rise of xenophobia, white supremacist extremism, far-right politicians in Europe and North America, and the apparently shock result of 'Brexit', have been portrayed as a worrying retreat from a previously taken-for-granted progressive trajectory in world politics. Indeed, Brexit (that is, the voluntary self-exclusion of the UK from an institution that prides itself on its soft power and attractiveness of membership) has produced something of a trauma in Britain and a state of shock amongst the UK's 'liberal' partners. Both the rise of nationalism and the refugee crisis have exposed a deep inhospitality in Europe that attack the very essence of a self-perceived cosmopolitan European identity. The close timings of these political developments have produced a sense of crisis in the EU project, as if we are witnessing a watershed in global politics where years of moral and political progress are now in retreat. Indeed, numerous commentators and politicians feared that the very principles of the Enlightenment now seemed to be at stake. ${ }^{2}$ However, is this in fact the case? Is the current inhospitality of the West a departure from Enlightenment norms, or rather should it be viewed as a logical continuity with Europe's normative roots?

${ }^{2}$ The Economist, 'Liberalism after Brexit, The Politics of Anger', 2 July 2016 (accessed on 15 March 2017 at http://www.economist.com/news/leaders/21701478-triumph-brexit-campaign-warning-liberal-internationalorder-politics ; Stephen Kinzer, 'The Enlightenment Had a Good Run', The Boston Globe, 23 December 2016 accessed on 15 March 2017, at https://www.bostonglobe.com/opinion/2016/12/22/kinzer-xml/5EGz2XG3Txum3eslWzSO3N/story.html; Andrew Graham, 'Britain's Values Were Founded in Europe - How Can We Leave?', The Guardian, 1 April 2016, accessed on 15.3.17 at https://www.theguardian.com/commentisfree/ 2016/apr/01/values-founded-europe-how-can-we-leave-law-freedom-religion ; Bernard-Henri Levy, 'Brexit Marks a Victory of Demagoguery Over Democracy', The Haaretz, 26 June 2016, accessed at http:// www.haaretz.com/opinion/1.727220; Pinkaj Mishra, 'Welcome to the Age of Anger', The Guardian, 8 December 2016, accessed on 15 March 2017 at https://www.theguardian.com/politics/2016/dec/08/welcome-ageanger-brexit-trump 
To understand those roots, one ought to return to early debates on hospitality. While the term itself has largely fallen out of favour in academic and policy discourse, ${ }^{3}$ Gideon Baker makes the case for a deeper study of hospitality in International Relations, particularly given that the notion of the stranger and his/her rights has been so central to the discipline. ${ }^{4}$ Indeed it used to be at the forefront of concerns in world politics, as can be gleaned from the weight of thinking devoted to the stranger and the 'other' by the likes of Hobbes, Vattel, Vittoria, Pufendorf and not least Kant, who features most prominently as the acclaimed inspiration for contemporary cosmopolitans and theoretical analogies of the EU. ${ }^{5}$

From a theory perspective, then, there is a sense among those working on hospitality, such as (among others) Baker, Cavallar, Niesen, Benhabib, Bulley, and their forerunner Derrida, that they are rejuvenating a forgotten legacy of international political theory that preceded theorising on cosmopolitanism. For them, its historical role in informing existing political norms, and its potential for shedding light on cosmopolitan tensions, should receive greater credit. Thus Baker calls for a renewed engagement with hospitality to 'retrieve' those early 'hotly contested' debates in international theory. It is this framing of hospitality that helps to reassert the notion that it has been a constitutive tradition in European epistemology, which in itself has significant implications for the way we view current trends in western politics.

This article, then, can be seen in part as a response to Baker's call. But given the illustrious list of thinkers on hospitality, why do we need a renewed focus on Immanuel Kant? In short, no other thinker on hospitality has received as much attention as has Kant, and arguably none has had the same level of influence on contemporary scholars. Of all the early theorists on hospitality, Kant is deemed to be pivotal for bringing hospitality out of the realm of pure ethics into politics, thus shifting hospitality from an absolute but impractical charity, to a practicable legal right. As Judith Still

\footnotetext{
${ }^{3}$ Writing in 2002, Cavallar states 'there is virtually no literature on international hospitality, in spite of more recent enthusiasm about Kant's cosmopolitan right'. Georg Cavallar, The Rights of Strangers: Theories of International Hospitality, the Global Community and Political Justice since Vitoria (England, Ashgate Publishing 2002), 5. Since then the dearth has partially been addressed through works by Gideon Baker, Cavallar himself, Dan Bulley and Seyla Benhabib.

${ }^{4}$ Gideon Baker makes this case more fully in his edited volume: Gideon Baker, ed., Hospitality and World Politics (New York, Palgrave Macmillan, 2013), 1-2.

${ }^{5}$ See Anthony Pagden and Harrry C. Black, 'Introduction' in Anthony Pagden, ed., 'The Idea of Europe from Antiquity to the European Union' (Cambridge: Cambridge University Press, 2002), 1-32.
} 
states, Kant 'produced a key reference point for cosmopolitan theories'. ${ }^{6}$ Georg Cavallar explains the general consensus on the significance of Kant by stating, ' $[\mathrm{h}] \mathrm{e}$ is a climax and turning-point in the debate on natural law...Kant's cosmopolitan right is the last major contribution to international hospitality in this natural law tradition' - and, as he goes on to argue, it is natural law that forms the roots of contemporary human rights doctrines. ${ }^{7}$ Robert Post states: '[Kant] is one of our most useful philosophical resources in regard to these difficult questions [on cosmopolitanism] ${ }^{8}{ }^{8}$

Moreover, unlike other modernist thinkers, it is Kant's cosmopolitan law that is most often applied to the context of present-day institutions. Despite more recent interventions on hospitality, most notably from Levinas and Derrida, ${ }^{9}$ it is Kant who remains the primary reference point for cosmopolitan scholars. Derrida is a high critic of Kant, relying instead upon Levinas in his promotion of absolute hospitality. This shifts it into the realm of ethics, and further away from politics and legal philosophy. But for contemporary cosmopolitans, it is precisely Kant's attempt to bridge ethics with pragmatism that makes his work appealing and ever-relevant. Thus Benhabib cites Kant's stipulation against rejecting the one who might be in danger from destruction, as a direct forerunner to the Geneva Convention's prohibition against 'refoulement' (i.e. transferring an asylum seeker to a third country where they are likely to be under threat). ${ }^{10}$ Cavallar has no qualms in making a direct linkage between Kant and the contemporary, arguing that Kant's most important contribution to human rights law is 'probably the European Convention on Human Rights'. ${ }^{11}$ Habermas, ${ }^{12}$ Held, Daniele Archibu-

${ }^{6}$ Judith Still, Derrida and Hospitality, Theory and Practice (Oxford: Oxford University Press, 2010), 34.

${ }^{7}$ Cavallar, The Rights of Strangers, 7-9.

${ }^{8}$ Robert Post, ed., 'Introduction', in Seyla Benhabib, Another Cosmopolitanism (Oxford University Press: Oxford 2008), 88.

${ }^{9}$ See Jacques Derrida, On Cosmopolitanism and Forgiveness, trans. Mark Dooley and Michael Hughes (London: Routledge, 2001).

${ }^{10}$ Seyla Benhabib, The Rights of Others: Aliens, Residents, and Citizens (Cambridge: Cambridge University Press, 2004): 31-5.

${ }^{11}$ Cavallar, The Rights of Strangers, 10.

12 Jurgen Habermas, The Divided West (Cambridge: Polity Press, 2006). 
gi, ${ }^{13}$ Garrett Wallace Brown ${ }^{14}$ and even realists such as Robert Kagan, ${ }^{15}$ have all suggested the EU is some kind of practical manifestation of Kantian cosmopolitanism, citing as evidence institutions such as the European Refugee Protection Programme, the European Refugee Resettlement Programme, the EU's focus on human security and democracy, and dilution of national borders.

However, despite these linkages, Europe's response to asylum seekers and immigrants has clearly exposed the fragility of Europe's cosmopolitan norms, particularly when put under strain and when they are in the most need. With deeper scrutiny, it becomes clear that this is the culmination of a longstanding ambivalence towards non-European asylum-seekers, exposing the shallowness of EU asylum policy - thus to suggest the inhospitality witnessed in recent years is the result of increased strain under crisis is insufficient, and is an example of foreclosure of debate on the issue. To view the recent, narrow electoral defeats of far-right political parties in Austria and France as a preservation and restoration of hospitality overlooks the extent to which Liberal parties are also products and trustees of an inhospitable framework. And to cite fear and reactionism as the primary factors for current inhospitality absolves states and individuals from explaining the more deep-seated, ontological, normative and epistemological reasons for exclusionary policies and behaviour.

Indeed, Brown acknowledges that out of three possible measurements of a Kantian cosmopolitics - domestic republicanism, international commerce and universal hospitality - the EU has fared the worst in the last pillar. ${ }^{16}$ Essentially he is arguing that the EU is not Kantian enough. He rightly criticises the institution of the EU and its current practice, but does not interrogate the principle of Kant's hospitality itself. In contrast, Seyla Benhabib has arguably done the most to critique the limits of Kantian hospitality in the face of the refugee plight. Given the plethora of cosmopolitan authors, this article narrows the focus on Benhabib's reading of Kantian hospitality since her work of-

\footnotetext{
${ }^{13}$ Daniele Archibugi, 'Immanuel Kant, Cosmopolitan Law and Peace', European Journal of International Relations 1, no. 4: (1995): 429.

${ }^{14}$ Garrett W. Brown, 'The Laws of Hospitality, Asylum Seekers and Cosmopolitan Right: A Kantian Response to Jacques Derrida', European Journal of Political Theory (2010): Volume 9 issue 3, pp. 308-327

${ }^{15}$ Robert Kagan, Of Paradise and Power: America and Europe in the New World ( London, Atlantic Books, 2003) in which Kagan criticises the EU for its belief in a 'Kantian paradise', and uses that normative identity to contrast Europe against the US. The label was highly influential spawning a whole raft of counter-arguments from EU scholars, though few challenged the connection made between Europe and Kantian ideals.

${ }^{16}$ GW Brown, 'The European Union and Kant's Idea of Cosmopolitan Right: Why the EU is Not Cosmopolitan', European Journal of International Relations 20, no. 3 (2014): 671-93.
} 
fers an example of a nuanced, critical approach to cosmopolitanism, which nevertheless continues to draw inspiration from Kant.

This article explores three key arguments: firstly, it seeks to demonstrate the contradictions and limits within Kantian hospitality, and its links to colonialism and practices of racialisation. The acclaimed universalism of Kant's law of hospitality forecloses a discussion of its dualism, and erases the historical, racist context in which it was conceived. The prioritisation of concept over conception allows Kant's theory on race to be obscured from official discourse and framing of policies while it still courses through inherited perceptions and theories. Secondly, in making my case, I will be applying the notion of coloniality, coined by Quijano and later developed by Walter Mignolo, to the existing but small body of critical discourse on Kant and race. I am indebted to the work of scholars who have already explored Kant's racism, a debate initiated on the peripheries of philosophy, law and anthropology in the 1990s. Those working on philosophy of race such as Robert Bernasconi, Thomas McCarthy, Stuart Elden, Robert Louden, Jon Mikkelsen and more recently Lucy Allais have led the way in this regard. However, given the time that has elapsed, it is notable that their work has received surprisingly little scrutiny in political theory and virtually none in International Relations theory, and thus warrants renewed attention - I argue that the notion of coloniality provides a useful lens through which to do so, and a vehicle through which to apply those excavations to a contemporary context. My third aim is to explore the extent to which Kantian thought constitutes 'modern' cosmopolitanism, which upholds a selective approach to Kant's complete body of work. I seek to draw greater attention to the inadvertently complicit role of second-generation cosmopolitans in the erasure of race from the study of Kant. While EU policy is not the focal point of this article, I close by drawing parallels between the collective erasure of race and racism in academia and European practice towards refugees and immigrants.

Section one will explore the legal arguments for and contra cosmopolitan law, as debated by scholars of hospitality and cosmopolitanism, with specific focus on the arguments of Benhabib and Niesen. Section two will address coloniality and the racial logic at the heart of Kant's framework. Section three will then return to cosmopolitan thinkers and European policies to demonstrate the continued legacy of Kantian racism through academic complicity. The lack of engagement with race and coloniality by cosmopolitan scholars is remarkable, validating the argument of decolonial scholars that limited temporal and spatial frameworks have facilitated this blindspot. Through its erasure, this racist logic is unwittingly transmitted by cosmopolitan scholars who uphold both Kantian principles and the efficacy of the EU as a vehicle. 


\section{Interrogating the Limits of Kantian Hospitality}

If the EU proudly purports to have inherited the hospitality in Kant's principles, it is reasonable to suggest Europe has also inherited the less-noted vestiges of inhospitality to be found in Kant's work. Modern-day cosmopolitans, 'neo-Kantians' as they have been dubbed, do recognise such limitations and have been active in critiquing them; ${ }^{17}$ in turn they have used that critique to generate an upgraded cosmopolitanism, inheriting some of the core aspects of Kantian hospitality. This raises an interesting question regarding the role of critical Kantians: are they breaking down the illusory nature of hospitality in Kant's laws, or in fact helping to perpetuate it via a more palatable upgrade?

To begin with, it is necessary to adumbrate the first of Kant's legal principles that necessitated an additional, derivative cosmopolitan law. Kant separated domestic law and the law between states, from the law of hospitality. The law of states is dependent on, and a product of, the stabilisation of property claims under private law. Under private law (that is on a domestic level within a state), Kant makes provisions for unilateral claims to property - arguably the most extreme end of hospitality, in which 'communication' is expressed via residence and appropriation. The stabilisation of property claims are seen as an instrumental measure towards the establishment of civil laws, justified by the caveat that it can only proceed via a common will to begin with. ${ }^{18}$ This right to acquisition can be seen as an extension of Kant's understanding of the innate human right to communicate. Moreover, for Kant, this is a means towards progress of human society; for Kant, 'unowned objects' reflect an unruly 'state of nature', which in turn is a threat to state-building and the regulation of society. He states in Perpetual Peace:

A human being (or a nation) in a mere state of nature... .already wrongs me just by being near me in this condition, by which he constantly threatens me; and I can coerce him either to enter with me in a condition of being under civil laws or to leave my neighbourhood. ${ }^{19}$

\footnotetext{
${ }^{17}$ See Jacques Derrida, Adieu; Dan Bulley focuses on Derridean hospitality rather than a Kantian one, see for example, 'Home is Where the Human Is? Ethics, Intervention and Hospitality in Kosovo', Millennium: Journal of International Studies 39, no. 1 (2010): 43-63; Benhabib, The Rights of Others.

${ }^{18}$ Baker, Hospitality, 54-5.

${ }^{19}$ Kant, 8: 349 cited in Peter Niesen, 'Colonialism and Hospitality', Journal of International Political Theory Vol 3, Issue 1, (2007): PP. 90-108
} 
Thus in private law, the appropriation of 'unowned' territory, is tied to the use of coercion to 'establish a civil union....and bring these human beings (savages) into a rightful condition' ${ }^{20}$ This entails a forcible right to hospitality, not unlike Vitoria's absolute hospitality favouring European colonisers in South America, ${ }^{21}$ with an important caveat that I will address below. From this condition of domestic socio-political regulation stemming from a stabilisation of property rights, Kant constructs international law that enables the regulation of relations between states that have undergone similar processes of domestic 'civilisation'. In doing so, he is purposefully universalising his principles of private and public law, with the intent that this will facilitate an eventual, global cosmopolitics. It is these principles of Kant's perpetual peace which are at the heart of current cosmopolitan thought and so often associated with the European project.

At first glance, these lofty principles also carry a more ominous possibility, in that they appear to erase colonialism from the debate, and simultaneously provide a justification for colonialism via the legalisation of unilateral property claims. If Kant's prioritisation of the state as a means to global peaceful relations, and his provisions for private law (entailing both appropriation and coercion) are universalised - as indeed he prescribes - then it would go further than Vitoria's carte blanche for absolute hospitality, in that he not only permits but advocates the appropriation of property and permanent residence of territory.

However, and crucially, Kant mitigates against this interpretation and application of his private law by introducing cosmopolitan law - that is, a universal hospitality that he marks out as distinct from domestic hospitality (though he himself does not use the latter term).

The key discussions of hospitality are to be found in Kant's Perpetual Peace and in the Doctrine of Right, as a means to complete Kant's formula for a global public law - the triumvirate of state law, international law and cosmopolitan law are described as the architecture needed for a global 'civil constitution'. ${ }^{22}$ Kant lays out a cluster of legal rights including the following: the right to 'present oneself for society' i.e. a basic communicative right; moreover this could reflect a range of purposes, from civil association, 'neighbourhood' or simply entertaining company. Alongside these are legal obligations: a duty to not prevent or hinder the expression of the above rights; and ensuring that the one expressing their right is not allowed to perish if they are turned away. The latter does not mean the host has no right to reject, but rather any rejection is conditional on the guest's safety of

\footnotetext{
${ }^{20}$ Ibid., 6: 266 translation by Niesen, 'Colonialism and Hospitality'

${ }^{21}$ Baker, Hospitality, 44-6.

${ }^{22}$ Kant, 8: 349 in Niesen, 'Colonialism and Hospitality': 91.
} 
life. The first obligation also means the communication (the claim for hospitality) cannot be ignored, but must at least be acknowledged. ${ }^{23}$ The most significant prescription for hospitality to 'strangers' is to be found in the following passage:

Hospitality means the right of the stranger not to be treated as an enemy when he arrives on the land of the other. One may refuse to receive him when this can be done without causing his destruction; but, so long as he peacefully occupies his place, one may not treat him with hostility. It is not the right to be a permanent visitor that one may demand. A special contract of beneficence would be needed in order to give an outsider a right to become a fellow inhabitant for a certain length of time. It is only a right of temporary sojourn, a right to associate, which all men have. They have it by virtue of their common possession of the surface of the earth, where, as a globe, they cannot infinitely disperse and hence must finally tolerate the presence of the other (Kant 1795).

Kant is clear that hospitality is not merely an expression of charity or faith, as it may have been practised in the pre-Enlightenment era, but a legal right which belongs to, seemingly, all human beings, insofar as they are viewed as potential participants in a future world global citizenship. ${ }^{24}$ Moreover, Kant envisaged this hospitality as being practised between hosts and strangers hailing from different and diverging civic entities.

Benhabib does offer a strong endorsement of Kantian hospitality, which I will address in more depth later in the article. But it is necessary to first explore her criticism of Kant. Benhabib questions the limitations Kant places on hospitality: that is, that the host does have the right to turn away the guest, having received his/her claim and having assured against any danger to him/her as a result of this refusal. She uses Kant's principle of hospitality as the foundation for existing norms on refugee asylum, and in doing so seeks to identify ways in which the above limitation also contributes to a limited refugee/asylum system today. She is willing to concede, here, that it is Kant who limits the rights of refugees, not merely the lack of EU policy implementation.

She notes that the Kantian right to visit is enshrined by law, but the right to be a permanent visitor requires a special agreement, 'a contract of beneficence' between host and guest. ${ }^{25}$ She cites various examples of this 'special privilege' already being offered to visitors in the early modern peri-

\footnotetext{
${ }^{23}$ Ibid., 94.

${ }^{24}$ Benhabib, The Rights of Others, 26.

${ }^{25}$ Ibid., 28.
} 
od, demonstrating the practical viability of this provision, such as pre-Revolutionary France which offered professional residency and property rights to certain visitors, and permanent asylum given to Jews throughout Northern Europe during the Inquisition. However, under Kant's laws, the shift from charity or tradition to a rights-based system produces a new 'juridical and moral ambivalence that affects discussion of the right of asylum and refuge to this day'. ${ }^{26}$ This is where it is more useful to go back to Kant, rather than more recent critics such as Derrida, since Kant overtly seeks to move the discourse of hospitality out of the realm of pure ethics. His work seeks to address a practical conundrum and in turn produces practical questions. Thus, while there is a duty on the host to prevent a visitor from being endangered, what duty is there to go beyond this basic right, if any? There may be a duty to provide a right (temporary visit), but no duty to provide a privilege (permanent stay). Moreover, if the duty is enforced by law, does this remove the need to offer protection based on a shared humanity? And by extension, who does the enforcing if Kant explicitly negates the need or desire for a supreme executive governing body. Such questions, which Benhabib identifies, have very real implications for institutions like the EU, for their norms and practice.

Thus, Benhabib concludes that the law of hospitality is a 'voluntarily incurred obligation' since it succeeds in decoupling it from the 'instability' of faith and charitable motivations, but at the same time cannot be enforced by any sovereign power, neither spiritual (a particular anathema for Kant and his fellow modernists) nor temporal. Moreover, there is enough ambiguity over what constitutes a danger to one's life to enable hosts to shirk even the voluntary obligation with legal justification - for example, the economic migrant is often refused entry without moral censure, but what if $\mathrm{s} /$ he is escaping poverty or destitution that in a slow and insidious way endangers her/his life? Finally, just as death and danger are ambiguous terms, so is the host's right to preserve life. Should this only be understood in an existential light, or can it be extended to mean 'way of life'? ${ }^{27}$ Once again, this lack of enforcement and such inherent ambiguities in Kant's own legal philosophy demonstrates the limitations to hospitality go beyond policy and are to be found at the intellectual level.

However, Niesen argues that this interrogation of Kantian hospitality is arguably underselling one of its most important functions. He acknowledges Benhabib's critique, that while these communicative rights are far-reaching, the limits seem 'overly restrictive at first' ${ }^{28} \mathrm{He}$ also agrees that, despite its centrality, Kant's legal philosophy on hospitality and the extent to which the norm applies,

\footnotetext{
${ }^{26}$ Ibid., 28.

${ }^{27}$ Ibid.,,35.

${ }^{28}$ Niesen, 'Colonialism and Hospitality', 90.
} 
have remained elusive. Kant did not envisage hospitality to necessitate refuge, but chiefly the right not to be treated as an enemy when arriving on foreign soil - this has come to be associated with a number of fairly diverging interests, from the humane treatment of refugees, to the rights of free and fair trade, to democratisation and global citizenship. The multitude of causes found in Kant's laws merely reinforces the notion of their ambiguity.

Nevertheless, Niesen argues that critical scholars have misinterpreted Kant's conditional hospitality as encouraging discrimination against non-Europeans, when in fact it stemmed from a principle that was meant to favour non-Europeans. With the imposition of limitations, Kant exhibited an awareness that unconditional hospitality and right to communication could be abused by European guests seeking to colonise non-European territories abroad. Benhabib touches upon a similar self-critique when she states her arguments are somewhat anachronistic: Kant's hospitality was not meant for the poor and needy seeking refuge, she concedes, but 'rather the Enlightenment preoccupation of Europeans to seek contact with other peoples and to appropriate riches of other parts of the world' ${ }^{29}$

Thus the key norms to emerge from Kantian hospitality were the regulation of European travel and restraint against imperialism. Indeed, for Niesen, the entire point of cosmopolitanism is not about global citizenship or refugee protection, but a critique against European colonialism, which he argues can only be appreciated when situating Kant's laws within the historical context of colonial expansion. Thus refreshingly Niesen does not abstract the concept from its historical conception.

A key 'loophole' in contemporary norms that was oft-exploited by European colonisers, and under-acknowledged by theorists of the time, was the 'systematic gap' that existed beyond relations within a state or relations between states. With no distinct laws applying to relations between state and non-state people, a vacuum was created for extraordinary practices that could be justified by the lack of legal precedent or guidance. Treating such relations akin to intra-state or inter-state relations was deemed to be at the heart of rampant colonial abuses, and thus a distinct category was required to close the gap. Thus Kant's cosmopolitan law, unlike the work of numerous other Enlightenment thinkers, makes colonialism visible with this mitigation, and also (apparently) makes colonised subjects visible in that cosmopolitan law can be deemed as a protection of the rights of non-state peoples: in a post-'westphalian' context, it is easy to see why one might imagine non-state referring to the rights of non-Europeans, since the Kantian (read 'civilised') state was a decidedly European one.

\section{Kant, Race and Coloniality}

\footnotetext{
${ }^{29}$ Benhabib, The Rights of Others, 37.
} 
Niesen's work is important, not only because it provides an exegetically-based moral justification for Kant's limitations to hospitality, but also because it (a) reintroduces historical conception into our reading of Kantian theory, and (b) (inadvertently) provincialises Europe and Kantian theory despite its claims to universalism. ${ }^{30}$ Niesen's arguments reassert the fact that Kant's law on hospitality was clearly developed with Europeans in mind. The limitations on hospitality are imposed because of European behaviour in the colonies - thus it cannot be forgotten that the law is constituted by that historical context within which Kant's hospitality was conceived. Given that is the case, it is notable that there is no mention of race in Kant's work on hospitality. Niesen does highlight Kant's anti-imperialism, but his detailed analysis also serves to emphasise the absence of any discussion of racial logics that prevailed at the time. In this section I will discuss the dual erasure and promulgation of racism within Kant's legal-political philosophy, geography and anthropology and situate it within Quijano's and Mignolo's frameworks of coloniality. In this way I seek to tie the work of philosophers of race more explicitly to decolonial studies.

One of the main reasons why Kant's cosmopolitan provincialism is overlooked is because he situates himself in an anti-imperialist camp, ${ }^{31}$ and in doing so gives the impression that he believes in the rights of non-Europeans. Thus, why should his laws of hospitality not be expanded to non-Europeans?

What allows this assumption to prevail is the failure of contemporary scholars to distinguish between colonisation on the one hand, and racism as a preceding facilitating condition on the other. ${ }^{32}$ For example, Kant's anti-imperialism is a condemnation of colonisation as a historical event that can be rectified by an ahistorical law. Such condemnation, however, does nothing to challenge the faulty premise that colonisation 'happens' because of need and greed (both rational reasons), with no men-

\footnotetext{
${ }^{30}$ Ian Hunter makes the case for historicising Kantian thought by situating it within the philosophical and political milieu of his time. However, he does not draw attention to the historical context of imperialism and racism in Europe. See 'Kant's Political Thought in the Prussian Enlightenment' in Kant's Political Theory: Interpretations and Applications, ed. Elisabeth Ellis (Pennsylvania, Pennsylvania State University Press, 2012).

${ }^{31}$ J. Hobson, The Eurocentric Conception of World Politics (Cambridge: Cambridge University Press, 2012), $62-4$.

32 Walter Mignolo, 'The Geopolitics of Knowledge and the Colonial Difference', The South Atlantic Quarterly 101, no.1 (2002): 57-96.
} 
tion of the philosophy which produces and incentivises this colonisation, and no mention of the geographical particularity of appropriation - a particularity that is based on race.

Thus for Kant, once colonisation is abolished as a practice, only then will Europeans exemplify true cosmopolitanism which might then usher in a perpetual peace; this is evident from Kant's view that 'a violation in one part of the world is felt everywhere' 33 indicating that colonisation has just as much capacity to hurt European civilisation as those colonised. The importance of hospitality (and thus an end to colonialism) as a means towards a peaceful end can also be gleaned from the following statement of telos: 'In this way [i.e. via universal hospitality], continents distant from each other can enter into peaceful mutual relations...thus bringing the human race nearer and nearer to a cosmopolitan constitution'. 34

While Kant focused only on the promise of civilised communities achieving their telos through the end of colonisation, ${ }^{35}$ present day cosmopolitans have interpreted that watershed as an enabler for non-Europeans to claim the same cosmopolitan rights as Europeans. No wonder, then, that leftist pressure for decolonisation in the mid-20th century coincided with the establishment of the global human rights regime, a timely rupture for a new global politics (so it seemed).

However, Kant's condemnation of colonisation rather than racism foreclosed an interrogation of the latter; ${ }^{36}$ this foreclosure was even more emphatic once decolonisation produced a supposed new present, a discontinuity that thus resolved the injustices of the past and further distanced Kantian concepts from their historical conception.

Here it is necessary to turn to Quijano's seminal work on coloniality, later built upon by Mignolo. In Quijano's definition of the concept, he ties capitalism, racial hierarchies, and racist epis-

${ }^{33}$ Immanuel Kant, 'Perpetual Peace: A Philosophical Sketch' in Kant: Political Writings, eds. H.B. Nisbet and H.S.Reiss (Cambridge: Cambridge University Press, 1991), 106.

${ }^{34}$ Ibid., 107-8; this interpretation of Kant's critique of imperialism is also reflected in G.W. Brown's chapter "Between naturalism and Cosmopolitan Law" in Baker, Hospitality, 113.

${ }^{35}$ Kant's review of the work of his student, Herder, sheds more light on his racialised notions of telos. There Kant couples global civilisation not just with cosmopolitanism, but specifically with the white race; non-Europeans, meanwhile, were ever-dependent on Europeans to expose them to reason via commerce and war (my thanks to the anonymous third reviewer for noting this). Thus, despite his condemnation, Kant also proffered a 'silver lining' to European imperialism. Moreover, Kant's telos resided exclusively in European agency: it simultaneously justifies commerce and the right of hospitality - cosmopolitan scholars follow suit but strip commerce of its colonial underpinnings.

${ }^{36}$ I borrow this term from Barnor Hesse's work, see 'Escaping Liberty: Western Hegemony, Black Fugitivity' Political Theory 42, no. 3 (2014): 288-313. 
temologies in a matrix of 'coloniality' ${ }^{37} \mathrm{He}$ argues this matrix was purposefully constructed, taught as scientific fact and upheld as a normative belief in Europe and then the Americas. Quijano's matrix enables one to identify the more hidden facilitators of colonisation, these being: modernity; an economic system that enabled and even required the dispensing of human lives; and knowledge that helped to codify and justify racism through 'scientific fact'. This knowledge system involved, to give one example, the separation of mind from the body, the identification of humanness with the mind, and a subsequent hierarchy in which Europe came to be viewed as the locus of reason and thus humanity, while non-Europeans were viewed as mere bodies deficient of humanity. The function of this matrix was epitomised by the slave trade, first between the Americas and Europe, and then Africa. It is this knowledge system and matrix that imbues the conception of Kant's work, from which his concepts cannot be divorced.

Mignolo developed this to distinguish colonisation (the primary concern of postcolonialism, and a historical event redressed by decolonisation), from coloniality (the primary concern of decolonialists). Unlike the historical event of colonisation, coloniality relates to epistemologies, ways of thinking, and where one is doing that thinking. So Quijano argues that while the 'formal system of political domination by western European societies over others seems a question of the past' the specific colonial structure of power that enabled it is not. ${ }^{38}$ In his 2002 article, Mignolo goes on to articulate a key limitation with 'anti-colonialism', for it implies that colonisation preceded and produced coloniality, and assumes that with abolition of the former the latter would also dissolve. ${ }^{39}$ But in fact, colonisation, along with modernity, was a derivative of coloniality. It was the matrix of coloniality that 'inspired' colonial activity. It is the activity that Kant condemned, but both conception (the knowledge system and its practices at the time) and concept (matrix of coloniality that upheld racism) remained unchallenged. ${ }^{40}$ As Mignolo argues, the colonial difference - between the colonisers and colonised - that was birthed by coloniality, thus never dissipated with decolonisation. Thus

\footnotetext{
${ }^{37}$ Aníbal Quijano, 'Coloniality and Modernity/Rationality', Cultural Studies 21, nos. 2-3 (2007): 168-78. Translated from the Spanish original by Sonia Therborn. This essay was originally published in Globalizations and Modernities. Experiences, Perspectives and Latin America, Rapport 99, no. 5 (Stockholm: Forskningsradsnamnden, 1999).

${ }^{38}$ Quijano, 'Coloniality of Power and Eurocentrism in Latin America', International Sociology 15, no. 2 (2000): 215-32.

${ }^{39}$ Mignolo, 'The Geopolitics of Knowledge', 81.

${ }^{40}$ For a broad articulation of this separation between theoretical concept and historical conception, see Katerina Dalacoura, 'Islam, Liberalism and Human Rights' (London, I.B. Tauris, 2007), 8.
} 
satisfaction with Kant's condemnation of colonialism, as demonstrated by Niesen, Post, Benhabib, Brown and other neo-Kantians, is not by any means a decolonial position.

Having introduced the concept of coloniality, and Kant's failure to challenge the prevailing racism that founded it, it is relevant to bring in here a second critical observation on Kant: that is his own views and knowledge production on race that served to embed that coloniality. Not only do political/IR theorists tend to consider Kant's laws in abstraction from the historical context of Europe, they also abstract it from Kant's own works on race and biology. ${ }^{41}$

Robert Louden can be credited with carrying out some of the most important work to reintroduce Kant's work on geography and anthropology to academic considerations of his legacy. ${ }^{42} \mathrm{He}$ charts a timeline of Kant's work to demonstrate the deep connections between his various disciplinary sojourns, particularly apparent between his oft-ignored work on physical geography, and his anthropology. For Kant, geography and climate have a strong bearing on the characteristics of the races, and together the two disciplines shape the 'condition of possibilities' in metaphysics and law. ${ }^{43}$

David Harvey takes issue with Kant's conditioning theory more explicitly, renders it clearly racist and poses the 'so what?' question: to what extent should this even matter for Kant's legal and moral philosophy? Thanks to the excavations of philosophers of race, Kant's pronouncements on race are not unknown, but they are oft treated as mere inconsistencies. To Pauline Kleingeld's credit, she does not make this case - she acknowledges and attempts to grapple with Kant's incontrovertibly racist pronouncements by situating them in a timeline that appears to absolve Kant's later works and suggests he recanted his racist views. ${ }^{44}$ But as Robert Bernasconi explains, this appears to be 'a new secular version of the old story of a deathbed conversion, which is retold more because it is comforting than because it meets the basic standards of historical scholarship'. ${ }^{45}$ The fact that there is an era-

${ }^{41}$ See Thomas McCarthy, Race, empire, and the idea of human development, Cambridge, UK: Cambridge University Press, 2009: pp. 48-58 on Kant's contribution to the racist ideological architecture of the time.

${ }^{42}$ For a summary of his findings see, R. Louden, 'The Play of Nature: Human Beings in Kant's Geography' in Stuart Elden and Eduardo Mendieta, Reading Kant's Geography, SUNY Press, Albany, 2011, 131-69.

${ }^{43}$ David Harvey, 'Cosmopolitanism in the Geography and Anthropology', in Elden and Mendieta, Reading Kant's Geography, p. 277.

${ }^{44}$ P. Kliengeld's updated argument in Kant and Cosmopolitanism (Cambridge: Cambridge University Press, 2012): 111; After a brief consideration of Kant's racism, and a decontextualised use of Mignolo's position on Kant, Cavallar endorses Kleingeld's argument in Georg Cavallar, Imperfect Cosmopolis: Studies in the History of International Legal Theory and Cosmopolitan Ideas (Cardiff, University of Wales Press, 2011), 66.

${ }^{45}$ Bernasconi, 'Kant's Third Thoughts on Race', in Elden and Mendieta, Reading Kant's Geography, 291. 
sure of race in Kant's later work - which even on its own represents an ethical problem - does not mean there is an abrogation of his earlier works. Crucially, Bernasconi builds on Larrimore's work to point out that Kant, in fact, had his key works on race republished precisely when he was promoting his better-known theories on cosmopolitanism: these being his 1785 essay on race in 1795, his 1785 and 1788 essays on race in 1793, all three essays once again in 1799, and his Anthropology in 1798 and $1800 .{ }^{46}$ Thus while it is true that in Kant's later writings he nowhere promotes racial hierarchy, he explicitly does so in earlier writings that were republished, suggesting he had the opportunity to revise his thoughts on race but chose not to do so - we can only presume because they had not in fact changed. Moreover, Bernasconi argues that even in his later works, Kant's seemingly moral position on the slave trade and colonisation is, in fact, an instrumentalist one - a case of Eurocentric self-interest rather than a concern for human equality. Thus Kant states: 'The trade in Negroes that is in itself a violation for Europe because of its consequences' ${ }^{47}$ Bernasconi also points out, in response to Kleingeld, that Kant's notes condemning the slave trade in Perpetual Peace, were notably excluded from the final published version. It is telling that at a time when the number of people denouncing the slave trade was growing, Kant chose not to join them.

It is worth acknowledging that there is not universal scholarly agreement on this subject; Eze, Serequerbehan, and the aforementioned Larrimore differ in their interpretation - though all make the case for reintroducing Kant's work on race into the debate. Eze and Serequerbehan consider Kant to have developed an ideological racist agenda that helped frame European philosophy, whereas Larrimore argues that Kant's race theory and political theory did not overlap and talked past each other thus any Kantian contribution to racist foundations in European political thought was unintentional. Should we then dismiss Kant's speculation on race as merely 'inconsistent', that familiar refrain when questions of race are put to international political theorists?

I would argue this approach must be contested, particularly given that Kant's work on race preceded his legal and moral philosophy without any explicit abrogation. ${ }^{48}$ Jon Mikkelsen similarly argues this point. Returning to the 'so what' question, he suggests that Kant should be read as a 'systematic philosopher', who meticulously built on his existing works, adapting and revising as he constructed a holistic architecture of ideas - Kant's various compartments of theory thus should not be

\footnotetext{
${ }^{46}$ Ibid., 300.

${ }^{47}$ Physische Geographie, cited according to the Akademie edition of Kant's gesamelte Schriften Vol. 23: 174, cited in Elden and Mendieta, Reading Kant's Geography? p. 302.

${ }^{48}$ Kant's works on natural history and geography were published between the 1750 s and 1780 s whereas his laws of hospitality appeared in Perpetual Peace in 1795.
} 
analysed in isolation from each other. Consequently, 'to consider any narrowly defined topic within the scope of...Kant's race theory or his philosophy of biology, could lead to a reconsideration of every other part of the critical project', indeed a 'complete reassessment of his contribution to the "project of modernity"". ${ }^{49}$ If considered in this light, it should lead to a major reconsideration of Kant's take on hospitality.

To attempt this reconsideration, one has a whole host of racist statements in Kant's work to choose from. One such is worth highlighting here, as it neatly showcases the way in which Kant played a key role in codifying racial hierarchies in a burgeoning knowledge system, which in turn shaped his cosmopolitan telos:

In hot regions, people mature earlier in every sense, but do not reach the perfection of the temperate zones. Humanity is in its greatest perfection in the race of the whites. Yellow Indians have somewhat less talent. Negroes are far lower, and at the bottom lies a portion of the American peoples. ${ }^{50}$

By extension, and arguably the most notable of his racist proclamations is Kant's assertion that 'all races will be wiped out...except for the white'. ${ }^{51}$ No indication is given that this should even be prevented; moreover it ties in with Kant's progressive approach to philosophy. ${ }^{52}$ Thus any vision of a teleological pinnacle for civilisation in Kantian cosmopolitan thought (that is, perpetual peace and a global citizenship) is predicated on a conviction that the only people remaining are white.

Moreover, in Kant's geography, we also see the signs of an emerging relationship between erasure and dehumanisation: whereas other races are described and placed in Kant's hierarchy, native

\footnotetext{
${ }^{49}$ Mikkelson 2013: 2 in "Kant and the concept of race : late eighteenth-century writings" / translated and edited by Jon M. Mikkelsen. Albany SUNY press 2013

${ }^{50}$ Physische Geographie, cited according to the Akademie edition of Kant's gesamelte Schriften Vol. 9: 228, cited by Walter Mignolo in The darker side of Western modernity : global futures, decolonial options, p. 341, Durham, Duke University Press
}

${ }^{51}$ Kant, Reflexionen zur Anthropologie no. 1520 give full publishing details cited in Mikkelson,"Kant and the concept of race : late eighteenth-century writings" / translated and edited by Jon M. Mikkelsen. Albany SUNY press 2013, p.8

${ }^{52}$ Kant saw nature, or 'providence' as playing a crucial hand in human progress, which did not rest on rational agency alone. Moreover, he saw the role of the former as converting evil developments within human progress into good - evil thus acts as a means through which humans can develop - see McCarthy 2009 Race, Empire: 60. Thus in Kant's telos, the 'natural' elimination of non-white races is one such evil that facilitates good. 
South Americans, deemed by Kant to be the lowest of races, are excluded from his matrix altogether. The erasure is not an oversight, it reflects Kant's ontology and directs his epistemology. ${ }^{53}$

These are some brief examples that demonstrate the particularly insidious and damaging nature of Kantian racism. Unlike Voltaire, Kant's racial descriptions are not gratuitous insults that can be dismissed as mere prejudice - they are given an air of scientific objectivity, couched in apparent logic. It is worth remembering the fluidity of the discipline of geography in this period - Kant's work contributed to the shaping of the discipline and sedimentation of core ideas about the relationship between territory and race; his anthropology subsequently built on this to forge a connection between race and morality; and finally his legal-political work consciously zoomed in on the so-called highest standard of morality - that of the white race. As Mignolo argues, Kant utilised and tidied up the messy transformations in cartography at this time, while his theories worked in tandem with Adam Smith's seminal works on capitalism, thereby shaping an interconnected matrix of coloniality. ${ }^{54}$ Kant's complicity in the establishment of coloniality is significant.

\section{The Erasure of Race in Cosmopolitan Discourse}

The previous section establishes the connection between Kant, racism and coloniality. In this section I argue that the erasure of race by political theorists and most notably critical Kantians, has helped to uphold the coloniality that Kant nurtured and contributed to; thus decolonial efforts directed towards Kant and modernist scholars should also address the underpinning coloniality in cosmopolitan literature.

Firstly, the ideological architecture that Kant's law of hospitality was conceived in does not receive sufficient attention in cosmopolitan literature. But more significantly, and more dangerously I would argue, is the second level of erasure: not only do political/IR theorists tend to consider Kant's laws in abstraction from the historical context of Europe (i.e. the conception), they also abstract it from Kant's other works on race and biology. ${ }^{55}$ Indeed Mikkelsen argues that English-language scholarship has universally ignored these numerous texts for the past two centuries. The previous section explored the work of critical philosophers who have made a major contribution in unearthing

\footnotetext{
${ }^{53}$ Mignolo, 'The Darker Side', 332.

${ }^{54}$ Ibid., 324.

${ }^{55}$ See T. McCarthy, Race, Empire: p. 48-58 on Kant's contribution to the racist ideological architecture of the time.
} 
Kant's earlier texts, but they have received remarkably little attention from international political theorists, while the work of prominent cosmopolitans appears to show outright unawareness of their existence.

Thus we have the following statements from cosmopolitan theorists, in evident contradiction of the reality of Kant's compendium of work. Robert Post states: 'For centuries, we have articulated issues of morality and ethics within a language of universalism. We have asked what we owe our fellow human beings, not what we owe our fellow-citizens'. ${ }^{56}$ Is this the case? While it is true that modernists adopted the language of universalism, Post's statement erases the inherent dualism that such language carried. Habermas also endorses Kant for his cosmopolitanism: while he does call for a 'reformulation', it is in fact to ensure Kant's continued relevance for today. Habermas goes on to suggest that the European Union provides a concrete example of Kantian cosmopolitics in practice, thus his position is one of the clearest, least critical, commitments to the 'universal good' of the Enlightenment and modernity. ${ }^{57}$ Other cosmopolitans may be less explicit in identifying Kant's impact on their work - David Held, for example, calls for a 'new global covenant' in his promotion of transnational institutions in place of the nation state, suggesting this is a new conceptual model; and yet, as Gary Browning argues, those such as Held still owe their moral and universalist insights to Kant. ${ }^{58}$ It is important to note that there are plenty theorists of hospitality and cosmopolitanism who do offer a critique of Kant, such as Gideon Baker who rightly highlights the tension in Kant's work between communication and property, ${ }^{59}$ which he argues is never fully resolved. However, none note that this tension exists within an imperialist epistemic, thus even if it was resolved it would fail to address the underlying ontological racism in Kantian theory.

This point is especially apparent in Benhabib's work. As demonstrated in section two, she is a 'second-generation' cosmopolitan who, as an exception to Browning's critique, quite explicitly refers to Kant, making clear his impact on an inherited cosmopolitanism today. Hence Benhabib is a particularly useful example to focus on, because she is open in drawing her inspiration from Kant. Hers is thus a more useful case for understanding the legacy of Kantian hospitality and coloniality, as opposed to the likes of Derrida. Derrida eschews Kant, who he argues is not ethical enough, in favour of Levinas. For him, Kant is explicitly treating hospitality as politics - cosmopolitics, as he coins it -

\footnotetext{
${ }^{56}$ Post, 'Introduction', in Benhabib, Another Cosmopolitanism, 1

${ }^{57}$ Gary Browning, Global Theory from Kant to Hardy and Negri (New York: Palgrave Macmillan, 2011), 117. ${ }^{58}$ Ibid., 114.

${ }^{59}$ Baker, Hospitality, 130-1.
} 
a treatment which he rejects. ${ }^{60}$ Other scholars of hospitality do make greater use of Kant, such as G.W. Brown, Cavallar and Habermas. However, I wish to focus to a greater extent on Benhabib since she has done more to highlight limits to Kant's law of hospitality, while still upholding its core principles and seeking to apply it to the present. It is this simultaneous critique and endorsement of Kant that I think is important for my argument, while not necessarily discounting the role of other cosmopolitan scholars - my critique would equally apply to them. Moreover, Benhabib critiques both Derrida and Levinas for seeking to address hospitality purely in the ethical realm as an unconditional right, whereas she seeks to treat it as a concept that intersects the political and legal realms, precisely because she is concerned with its practical implications. ${ }^{61}$ This very framing creates a distinction between a discourse approach and a practical-legal approach, and effectively she is bracketing Kant in the latter.

As highlighted in the earlier section, she offers a nuanced critique of the loopholes and ambiguities in Kantian hospitality, particularly as she seeks to explore its utility in relation to the currentday plight of refugees. ${ }^{62}$ This application serves to upgrade Kantian hospitality, thus reinforcing its place in contemporary reading and practice of hospitality. It is via this 'upgrading' that critical Kantians inadvertently help to transmit the embedded racial hierarchies within Kant's work.

My first example is illustrated in 'Another Cosmpolitanism' based on Benhabib's Tanner lectures, where she identifies three issues with Kantian cosmopolitanism that need resolving: Thus, 1) what are the delimitations of Kant's ontological foundations for hospitality? 2) What is the authority of enforcement? And 3) how does one resolve the tension that stems from demands of cosmopolitan justice and self-governance? She promises to address all three, but crucially in relation to the first question she states: 'my concern is less with the kind of ontological universe in which cosmopolitan norms can be said to exist, than with how these norms, whatever their ontological status, can shape, guide and constrain our political life' ${ }^{63}$ This short treatment of Kant's ontology is remarkable, and arguably can only be dismissed by one who is not personally implicated by his ontology. That ontology is laid out not in Kant's legal-political writings, but of course in his geography and anthropology - as we now know, a racist ontology that paves the way for an imperialist epistemic.

\footnotetext{
${ }^{60}$ Still, Derrida and Hospitality, 8.

${ }^{61}$ Benhabib, Another Cosmopolitanism, 157-9.

${ }^{62}$ Benhabib draws greater attention to the flaws in Kantian hospitality in The Rights of Others?

${ }^{63}$ Benhabib, Another Cosmopolitanism, 27.
} 
Overlooking ontology means cosmopolitans accept reason as the necessary foundation for the application of Kantian hospitality, but will rarely ask what happens if any community is deemed to be deficient in their rational capacities. The universalism assumed of Kant's cosmopolitan law is rendered more ambiguous due to Kant's regular interventions to insist on reason as the precondition for all his laws - it does suggest that he considers there must be numerous circumstances when reason is absent.

Rarely is this, or its implications, explored by cosmopolitans. And yet it is a necessary backdrop to consider because no law exists in abstraction from its societal and historical context, which continues to constitute that law until a deliberate separation takes place. Moreover, while laws can be regulated, ways of thinking and perceiving cannot. Contestation on Kant's speculative anthropology is effectively foreclosed through silence on the matter in his later works, and thus his knowledgeconstructions are never undone. This process is inherited and sustained by critical Kantians today, who grapple with the practical, legal, national and normative impediments to modern-day cosmopolitanism, but remain virtually silent, wilfully so, on the ontological 'impediments' of racism.

Given that cosmopolitans claim to be concerned about contemporary global ethics and practice, and given that the majority of the world's current refugee population are non-white and non-European, the lack of attention to the existing coloniality that fosters blatant inhospitality towards them is unconscionable. Before dealing with the legal limitations of Kantian hospitality, it is not unreasonable that they ought to focus on dismantling the coloniality that underpins the entire framework. Erasure and silence in this context becomes complicity.

The second example of 'upgrading' and erasure can be found in Benhabib's critique of contemporary practices of hospitality. Her critique centres on the obstructionism of the state, chiefly its impediments to provisions of human rights law, the disharmony between positive law and natural law, and state-imposed exclusion of those who live within but still are excluded from the polity. ${ }^{64}$

By tethering cosmopolitanism to democracy, she argues that cosmopolitan norms will eventually, and progressively, be absorbed within positive law via the will of the people, not dissimilar to the Wilsonian linkage between commerce, peace and domestic public opinion. Like Kant, she demonstrates a strong teleological approach, for she does not really demonstrate how these norms will be absorbed except through socio-economic means to mitigate the differentiation between ethnic groups - it is a materialist resolution rather than a conceptual-normative one. Her key conflict is with a nation based on ethnos, which contradicts her universalist ethical principles; thus she calls for an

${ }^{64}$ Post, 'Introduction', in Benhabib, Another Cosmopolitanism, 4. 
'unbundling' of ethnos 'from national belonging'. ${ }^{65}$ She identifies ethnicity as the primary obstacle to hospitality. Here she veers close to race, but race gets hardly a mention except once - and that is in a statement of dismissal. ${ }^{66}$

Benhabib goes on to make an explicit connection between Kantian cosmopolitanism and the EU - there is a seamless transition from one to the other in her commentary, where she explains why European federalism and the porosity of intra-regional borders demonstrate a movement towards a cosmopolitan realm. Is the EU structure a 'site of cosmopolitan consciousness?' she asks, noting the scepticism from her detractors. She argues yes, and that an unbundling of rights from liberal-nationhood has facilitated a far greater cosmopolitanism within Europe. She also argues that she would like to see liberalisation of naturalisation laws for those who come from non-European third countries, giving the example of a Moroccan who might potentially enjoy EU citizenship rights without becoming a national citizen of any European country first. But, just as is the case with Kant, she bypasses the coloniality that affects not just the immigrant's entry into Europe, but also his/her experience as a European citizen in which he or she is still considered an outsider. Brexit demonstrated the residual xenophobia that exists towards fellow Europeans, usually East Europeans - but of course, one or two generations down the line, offspring of the European immigrant will, on account of the colour of his/ her skin, be considered an insider, a privilege that may still not be afforded to second, third or fourth generation immigrants from non-white backgrounds. This likelihood (one which has been borne out historically) receives no attention from cosmopolitan authors - the experience of immigrants or refugees is flattened to only acknowledge the potential hostility in the initial encounter. But the variance in experiences that are created over generations is overlooked. Indeed, in the case study offered by Behnhabib, 'l'affair foulard', the schoolgirls of North African origin are still referred to as 'immigrants' by both Benhabib and Waldron, when they were in fact born in France and are therefore French citizens. Both scholars have reproduced the schoolgirls' otherness on account of their race, not on account of their birthplace. Benhabib gives significant weight to democratic citizenship and normative iteration as a vehicle for cosmopolitanism, as a replacement for national citizenship. ${ }^{67}$ But this underestimates the embeddedness of coloniality among that very demos. Such that even if one eliminated the nation, race would still be an unspoken delineator for exclusion.

\footnotetext{
${ }^{65}$ Benhabib, Another Cosmopolitanism, 171.
}

${ }^{66}$ There is one mention on Kant's description of non-white as 'mere auxiliaries to the commonwealth', thus Benhabib acknowledges that exclusion based on race is present in Kantian canon, but this is overlooked as unimportant and outdated. See Benhabib, Another Cosmopolitanism, 34.

${ }^{67}$ Ibid., 174. 
Indeed this exclusion is facilitated by Kant's law of hospitality, because it does not offer us an imaginary for the non-white, non-European visitor. Benhabib concludes with a final parting shot at the corporatisation of sovereignty under the banner of nationhood, which she sees as a key obstacle to Kantian hospitality. But this obfuscates the extent to which even a cosmopolitan Europe, with diluted national borders and a superficial increase in democratic norms, utterly fails to overcome the coloniality that Kant helped to entrench in the European imagination.

The above discussion allows me to conclude this section with a final argument that returns to the provincialism of Kant's hospitality. A few critical works on Kant have centred on the extent to which he did, in fact, condone some form of imperialism as a civilising mission for what Hobson has described as an intolerance for cultural pluralism, for the 'lawless savagery' of non-European people. But as has been explained, this intolerance still did not permit an abuse of cosmopolitan responsibilities bound upon European travellers. ${ }^{68}$ On this front, Kant at least, is clear. However, what has not been discussed is the extent to which Kant ever envisaged affording the same rights and responsibilities on those 'lawless savages' who sought to enter Europe. It has been taken as a given that the law is intended to be universal ${ }^{69}$ and thus can be applied to non-Europeans travelling to European shores as well - Benhabib's critique focuses on the limitations of the concept of Kant's cosmopolitanism, but does not question if its conception was ever inclusive of the non-European visitor. On doing so, one would find there is no categoric provision for this possibility.

We have no indication from Kant's political thought alone of whether he believed the hosts capable or requiring of reason - for him, the onus is on the guests. In other words, Kant's cosmopoli$\tan$ law was conceived with Europeans in mind, obviously capable of reason and thus required to use it to effect all his laws - private, international and cosmopolitan. The obligations placed on the host (and in Kant's historical context, they were likely to have been non-European and non-white) are not through faith, morality, not even via reason. The obligation is a legal one, whether they consented to it or not; while both Niesen and Benhabib suggest that the responsibilities of the (European) guest

${ }^{68}$ This reflects the tension, highlighted by Sereqeheban and McCarthy (see 2009 MacCarthy, Race, Empire: 66), between Kant's two approaches: his tolerance of functional evil that advances human progress, and his condemnation of evil that impedes moral progress. For Kant, imperialism may have been a means to spreading the benefits of European civilisation (and thus functionally worthwhile) but still warranted disdain on a moral level, and was to be viewed as an impediment to European moral progress. However, one can see a greater level of consistency between Kant's practical and moral theory if one recognises that for him, moral progress will flourish after nature has run its course.

${ }^{69}$ Brown, 'Between Naturalism and Cosmpolitan Law', in Baker, Hospitality, 112-16. 
renders the host with rights, all that is explicitly mentioned in Kant is that the guest has conditional rights which they can claim by law, with conditional obligations on the part of the host. Herein lies the major flaw in Benhabib's deliberate glossing over questions of ontology, for it means she fails to address or challenge any of these issues.

While it might not be fair to argue that Kant intended to exclude non-Europeans, it does mean there is sufficient ambiguity in the law to allow its application to be restricted to Europeans travelling abroad, while maintaining a silence on the rights of non-Europeans entering Europe. In a context in which there is an architecture of racist thought and practice, silence, neutrality, and ambiguity - what Larrimore calls Kant's 'quietism' - act as de facto endorsements of the existing framework and, crucially here, fails to provide an epistemology of hospitality for the non-European visitor. Niesen's aforementioned defence of Kant sheds light on the attention given to the non-European as a host, not as a guest. Indeed, considering Kant's celebration of voyage and exploration as traits of advanced civilisation, and considering Kant's speculation on an exclusively white world, it is likely that he did not see the likelihood of large-scale non-European voyage, and thus saw no need to provide for it in his laws of hospitality. Benhabib and her fellow cosmopolitans endorse and uphold Kant's telos what, then, do they have to say on his foundational, racist, condition of possibility for that telos?

That Kantian hospitality might offer a framework to address the plight of the non-European asylum seeker assumes a reciprocal dynamic in cosmopolitan law. But it was never intended as such because the likelihood is unaddressed in Kant's political theory and (by default) ruled out by Kant's race theory. Niesen argued that Kant sought to bridge the legal gap between private and public law, to prevent the practice of extraordinary and arbitrary measures in the realm of state/non-state relations. But, with the foundational assumption that his laws only applied to those capable of reason, amidst a prevailing view (which Kant helped to reinforce) that non-white people were deficient in reason, extraordinary and arbitrary practice outside of 'civilised norms' flourished instead of hospitality.

Applied to the current context, this has produced not just an illusion of Kantian hospitality in the face of the refugee crisis, but in fact an inversion of Kant's legal framework. Thus Kant's private law that advocated unilateral appropriation of property, meant for a domestic context, was applied to the 'real' savages in non-European territories, while the limitations on hospitality designed to restrain European abuses abroad is now twisted to apply to dangerous, irrational, threatening non-Europeans seeking entry to Europe. The abysmal record of European 'exploration' during the period of Enlightenment, and the need to ward off the threat, now constitutes European policies and perceptions on 
asylum-seekers and immigrants, though the intent and context of their 'visitation' is entirely different.

Such is the extraordinary nature of the non-white 'visitor' whose existence and claims carry no legal or moral validity in Enlightenment epistemology, that they are even denied the limited rights of hospitality prescribed by Kant. Thus with the contemporary example of the EU and its treatment of asylum seekers and migrants, we can see a reproduction of this Kantian logic. The practice that exemplifies this most is the scrapping in October 2014 of the EU's 'Mare Nostrum' search and rescue operations in the Mediterranean. Each year, thousands of immigrants and asylum seekers are extorted by traffickers to travel to Europe on over-crowded boats, which frequently capsize. The 'Mare Nostrum' rescue operations saved around 100,000 lives of migrants and asylum seekers since it began. The stark logic of the EU's decision to terminate this operation is to allow many hundreds of (non-white) people to perish simply in order to deter other would-be migrants from attempting entry. This not only contravenes Kant's stipulation that no traveller should be refused entry if their lives will be endangered; it contravenes the obligation of the host to at least acknowledge the traveller's claim for hospitality, even if the host reserves the right to reject it afterwards.

Its abolition and the resistance to refugee resettlement has not stopped people from making the hazardous journey, and the numbers of people drowning has only increased. To treat the thousands of migrant deaths at sea as ' accidents', as is often the case in political and media discourse, overlooks the political agency of the EU that enables this crisis to exist in the first place, but which also has the capacity to alter policy and possibly save thousands of lives. Instead, the migrants' existence, and their deaths, are erased from EU discourse and policy. One might ponder, is this really a violation of the Kantian hospitality it claims to uphold, or is it in fact a devastatingly accurate mirroring of his cosmopolitan law and its erasure of race? This is a question that cosmopolitan authors appear to be unequipped to answer because their framework is so deeply buried within a Kantian epistemology.

Cosmopolitans seek to bridge the tensions between sovereignty, ethnicity, democracy, and hospitality, to offer a more ethical, just solution to contemporary world problems. Whether acknowledged or not, they are bound to their Enlightenment heritage and turn to it frequently for inspiration. But modernist thinkers cannot offer a way out of the deepest of injustices in contemporary world politics, for their ontologies and epistemologies are steeped in coloniality. If the quest for an ethical and practical hospitality is sincere, greater attention needs to be given to frameworks of hospitality outside of the imperialist architecture. The archives of decolonial conceptualisations of hospitality are 
rich and substantial. ${ }^{70}$ Only by unbinding themselves from modernity, by engaging with alternative thinkers and epistemes, as well as alternative historical practices beyond the EU, can cosmopolitan scholars move beyond the coloniality of Kantian hospitality.

\section{Conclusion}

Europe's failure to uphold a basic universalist reading of cosmopolitan law warrants renewed focus not just on EU refugee protection mechanisms, but on its purported Kantian roots. Europe's inhospitality is not (as has often been suggested in media and political commentary, chiefly by those who are in fact sympathetic to the plight of refugees) a new and sudden development; rather, as Quijano and Mignolo have argued via the notion of coloniality, it is a reflection of an imperialist epistemic that has shaped academic discourse, perception and practice towards non-European, non-white races. This coloniality has been inherited by cosmopolitan theorists, or 'second-generation Kantians', who draw upon Kant's law of hospitality for their own ruminations on contemporary issues of asylum and refugees. Those that seek to 'upgrade' (rather than overturn) Kantian hospitality, such as Benhabib, do offer a critique of Kantian imitations on hospitality and the inherent ambiguity of his prescribed rights and obligations. But this critique reflects a 'problem-solving' approach set within the parameters of Kant's moral and teleological logic, to remedy and thereby preserve the relevance of Kantian hospitality.

Thus counter-arguments that seek to restore the critical potential in Kant's philosophy as a safeguard of non-European rights fails to look beyond the imperialist boundaries that his work is situated in. By provincialising and historicising Kant's legal framework, rather than treating it in abstraction from its historical and imperialist conception, one is able to restore the importance of race to Kant's 'system-building' theories. By excavating his works on geography and anthropology, it is possible to identify the constitutive effects of an erasure of race from Kant's legal-political theory on the one hand, and a simultaneous project of racist codification in Kant's natural history on the other.

\footnotetext{
70 The primary emphasis might be on non-English speaking authors, but in addition a fruitful example of a hospitality theorist breaking away from the traditional mould is Gideon Baker's article, 'The Spectre of Montezuma: Hospitality and Haunting', Millennium: Journal of International Studies 39, no. 1 (2010): 23-42. The article mines those archives to consider the historical conception of European notions of hospitality, inverts the focus towards the non-European hosts, and offers an alternative reading of hospitality that breaks the modernist monopoly in its conceptualisation.
} 
Rather than addressing this sizeable impediment in Kantian hospitality, cosmopolitan theorists have produced an upgraded Kantianism that continues to both obscure and reinforce his racist ontology and epistemology. While Kant's racism has been exposed by both decolonial theorists and philosophers of race, the same level of scrutiny has yet to be applied to cosmopolitan theorists and frameworks of hospitality. It is fitting therefore to conclude with a call for more decolonial scholarship on non-modernist epistemologies and practices of hospitality, which would challenge the eurocentric, cosmopolitan monopoly on the subject.

\section{Acknowledgements}

I am grateful to the Millennium editors and three anonymous reviewers for their invaluable input. My thanks to Anthony Lang and Meera Sabaratnam for their insightful comments on the first draft of the article; thanks also to Robbie Shilliam, Faye Donnelly, Vassillis Paipais, Maria Fotou, Khadijah Elshayyal, Hudda Khaireh and participants at the 2016 Millennium Annual Conference for their helpful pointers, questions and encouragement.

\section{Funding}

This research received no specific grant from any funding agency in the public, commercial, or notfor-profit sectors. 